JIPFRI, Vol. 5 No. 2

Halaman: 95-101

November 2021
JIPFRI (Jurnal Inovasi Pendidikan Fisika dan Riset IImiah)

https://doi.org/10.30599/jipfri.v5i2.918

\title{
Analisis Kebutuhan Pengembangan Modul Pembelajaran Fisika SMA Berbasis Pendekatan STEM
}

\author{
Yonira Mike Vindi Marta ${ }^{1^{*}}$, Ramli $^{2}$ \\ 1,2 Prodi Magister Pendidikan Fisika, Universitas Negeri Padang, Padang 25131, Indonesia \\ *E-mail: yoniramike@gmail.com
}

\begin{abstract}
Abstrak
Penerapan pendekatan STEM harus didukung dengan adanya bahan ajar yang sesuai dengan karakteristik dan kebutuhan peserta didik. Bahan ajar yang dapat mendukung pembelajaran mandiri salah satunya adalah modul. Namun, masih ada modul yang belum sepenuhnya memfasilitasi penerapan STEM dalam pembelajaran fisika.. Penelitian ini bertujuan untuk menganalisis kebutuhan modul berbasis pendekatan STEM dalam pembelajaran fisika. Penelitian ini merupakan penelitian deskriptif yang dilakukan melalui observasi di Sekolah Menengah Atas (SMA N 9 Padang) dengan sampel penelitian adalah siswa kelas XI. Analisis kebutuhan modul berdasarkan pendekatan STEM, meliputi analisis siswa, analisis kegiatan pembelajaran, analisis standar kompetensi lulusan, dan analisis penilaian. Instrumen dalam penelitian ini merupakan angket dan lembar wawancara. Hasil penelitian menunjukkan bahwa rata-rata peserta didik diperoleh 71,42, analisis kegiatan pembelajaran diperoleh nilai ratarata 92,84, analisis standar kompetensi lulusan diperoleh nilai rata-rata 91,84 dan analisis penilaian diperoleh nilai rata-rata 100 . Oleh karena itu, perlu dikembangkan bahan ajar fisika yang berupa modul berbasis pendekatan STEM.
\end{abstract}

Kata kunci: Revolusi 4.0, STEM, Pembelajaran fisika, Modul.

\begin{abstract}
The application of the STEM approach must be supported by the existence of teaching materials that are in accordance with the characteristics and needs of students. One of the teaching materials that can support independent learning is modules. However, there are still modules that have not fully facilitated the application of STEM in physics learning. Modules that have not fully facilitated the application of the STEM approach in learning physics. This study aims to analyze the needs of module based on the STEM approach in learning physics. This research is a descriptive study conducted through observations in Senior High Schools (SMA N 9 Padang) with the research sample being students of class XI. Analysis of module needs based on the STEM approach, including student analysis, analysis of learning activities, analysis of graduate competency standards, and assessment analysis. The instruments in this study were questionnaires and interview sheets. The results showed that the mean score of the students was 71.42, the analysis of learning activities obtained an average value of 92.84, the standard analysis of the competence of graduates obtained an average value of 91.84 and the assessment analysis obtained an average value of 100. Therefore, it is necessary to develop physics teaching materials in the form of modules based on the STEM approach.
\end{abstract}

Keywords: Revolution 4.0, STEM, Physics Learning, Module.

\section{PENDAHULUAN}

Seorang guru harus bisa menggunakan teknologi gital untuk mengikuti paradigma pembelajaran abad 21 memanfaatkan kesesuaian sarana komunikasi atau jaringan yang untuk mengakses, mengelola, memadukan, mengevaluasi dan menciptakan informasi sehingga memiliki fungsi dalam pembelajaran. Kesesuaian pada Permendikbud no 22 tahun 2016 tentang standar proses pendidikan dasar dan menengah. Pemanfaatan teknologi informasi dan komunikasi merupakan salah satu isi dari standar proses untuk peningkatan efisiensi dan efektivitas pembelajaran. Berharap guru mampu melakukan penerapan teknologi informasi dan komunikasi secara terintegrasi, sistematis, dan efektif sesuai pada situasi dan 
kondisi termasuk mampu memanfaatkan teknologi sebagai sumber belajar dan media pembelajaran $(\mathrm{JH}, 2018)$.

Upaya pemerintah menjawab tantangan ini dengan meningkatkan kualitas sarana dan prasarana. Wajibnya menggunakan bahan ajar yang relevan juga diatur dalam permendikbud No.26 tahun 2016. Seperangkat bahan terdiri dari materi, metode dan evaluasi pembelajaran tersusun sistematis dan menarik untuk mencapai tujuan pembelajaran yang telah ditetapkan disebut bahan ajar (Lestari,2013). Bahan ajar ada berbentuk cetak dan non-cetak. Bentuk bahan ajar cetak contohnya adalah bahan ajar modul. Modul adalah bahan ajar yang berisi komponen-komponen berbentuk paket program keperluan pembelajaran terisi tujuan, bahan, metode, alat dan sumber pembelajaran dan sistem evaluasi. (Majid ,2008) menyatakan bahwa terciptanya lingkungan siswa untuk belajar melalui seperangkat bahan ajar yang disusun secara sistematis ini disebut dengan modul. Sedangkan modul pembelajaran adalah suatu paket bahan pembelajar yang membuat penjelasan mengenai tujuan pembelajaran, lembaran petunjuk pendidik atau instruktur yang menjelaskan cara mengajar yang efisien, bahan bacaan bagi peserta, lembaran kunci jawaban pada lembar kertas kerja peserta, dan alat-alat evaluasi pembelajaran.

Pembelajaran abad 21 Selaras dengan revolusi 4.0 pada saat ini. Era pendidikan yang dipengaruhi oleh revolusi 4.0 disebut pendidikan 4.0. Pendidikan 4.0 merupakan program mewujudkan cerdasnya pendidikan melalui peningkatan merata pendidikan berkualitas memperluas akses, relevansi dalam pemanfaatan teknologi untuk terwujud pendidikan kelas dunia dengan menghasilkan peserta didik yang memiliki setidaknya 4 keterampilan abad 21 yaitu kolaborasi, komunikasi, berpikir kritis dan kreatif, mengacu pada standar kompetensi global dalam mempersiapkan generasi muda memasuki realitas kerja global dan kehidupan abad 21 .

Pendidikan 4.0 memiliki ciri-ciri memanfaatkan teknologi digital pada proses pembelajaran. Tanpa batas ruang dan waktu proses pembelajaran dapat berlangsung secara kontinu. Menurut Muhadjir Effendy (mendikbud) perlunya bidang pendidikan menambah lima kompetensi untuk peserta didik melalui revisi kurikulum untuk masuk era revolusi 4.0 dengan kemampuan berpikir kritis, kreatifitas dan kemampuan yang inovatif, memiliki keterampilan berkomunikasi, bisa berkolaborasi, dan punya kepercayaan diri. Penggunaan Pendekatan pembelajaran merupakan suatu cara yang digunakan oleh pendidik dalam melaksanakan proses pembelajaran untuk mencapai tujuan yang telah ditetapkan. Di era revolusi industri 4.0 pembelajaran perlu menggunakan suatu pendekatan yang dapat menjadikan peserta didik untuk berpikir kritis (critical thinking), kreatif (creativity), kolaboratif (collaborative), dan komunikatif (communicative). Pendekatan STEM salah satu yang bisa digunakan oleh pendidik. STEM (Science,Technology, Engineering and Mathematics) adalah integrasi lebih satu disiplin ilmu yang terintegrasi pada bidang pendidikan yang merupakan pendekatan baru bidang pendidikan. Pendekatan keempat aspek ini merupakan pasangan yang serasi antara masalah dunia nyata berbasis masalah pada pembelajaran (Torlakson, 2014). Berarti, pembelajaran dengan pendekatan STEM menjadikan peserta didik mampu mengaitkan permasalahan yang ada dengan fenomena yang terjadi dalam kehidupannya.

Pembelajaran dengan pendekatan STEM adalah meintegrasi pembelajaran sains, teknologi, teknik, dan matematika salah satu pendekatan diharapkan dapat membantu kesuksesan meningkatkan keterampilan abad ke-21 (Beers, 2011). Perkembangan pendekatan STEM dengan pembelajaran yang terkait pada lingkungan, membentuk terwujudnya sebuah pembelajaran langsung dihadapkan peserta didik bisa mendapat penjelasan langsung dengan kehidupan sehari-hari (Subramaniam et al, 2012). Pembelajaran dengan keterpaduan ilmu akan menjadikan peserta didik emperoleh pengetahuan da keterampilan secara utuh sehingga pembelajaran menjadi bermakna (Asrizal, 2015). Peserta didik dengan pendekatan STEM bukan sekedar tau mengenai konsep pada metode hapalan, lebih 
dari itu peserta didik memiliki pemahaman bagaimana konsep tersebut didapatkkan selanjutnya bisa mengaitkan konsep tersebut pada kehidupan sehari-hari. Pemilihan penggunaan pendekatan yang tepat pemilihan bahan ajar yang tepat sehingga mampu meningkatkan keterampilan befikir peserta didik terlatih dengan baik. Berdasarkan keutamaan pembelajaran dengan pendekatan STEM, perlu dikembangkan bahan ajar yang menerapkan pendekatan STEM. Bahan ajar yang dikembangkan modul fisika berbasis pendekatan STEM. Dengan demikian, kegiatan pembelajaran yang dilaksanakan diharapkan lebih efektif dan interaktif.

\section{METODE/EKSPERIMEN}

Jenis penelitian yang dilakukan adalah penelitian deskriptif. Penelitian ini merupakan suatu pe- nelitian dasar yang dilakukan. Penelitian deskriptif dilakukan untuk menggambarkan, menafsirkan, dan menjelaskan suatu variabel atau keadaan yang akan diteliti (Sukardi, 2007). Populasi pada peneli- tian ini yaitu seluruh peserta didik kelas XI MIPA SMAN 9 Padang dengan sampel diambil dari 33 peserta didik. Data penelitian ini berupa data deskriptif dan data kualitatif. Alat yang digunakan dalam mengukur suatu kejadian atau keadaan yang akan diteliti disebut instrumen penelitian (Sugiyono, 2017).

Instrumen pada penelitian ini berupa lembar wawancara yang diisi oleh pendidik dan kuesioner yang diisi oleh pendidik dan peserta didik. Skala pada kuesioner menggunakan skala Likert yang terdi- ri dari empat alternatif jawaban. Di mana, skor 1 menyatakan "tidak pernah", skor 2 menyatakan "kadang-kadang", skor 3 menyatakan "sering", dan skor 4 menyatakan "selalu". Selanjutnya, menjumlahkan skor setiap indikator pada masingmasing aspek lalu dikonversi ke dalam nilai dari rentang 0-100. Penyajian data statistik deskriptif pada penelitian ini disajikan dalam bentuk grafik dan dianalisis agar mudah dipahami. Nilai untuk setiap indikator dapat ditentukan dengan persamaan 1 (Arikunto, 2010).
Nilai $=\frac{\text { skor } \text { yang diperleh }}{\text { skor maksimum }} \times 100 \%$

(Arikunto, 2008)

Analisis data untuk menilai analisis kebutuhan pada masing-masing indikator yang meliputi analisis siswa, analisis kegiatan pembelajaran, analisis standar kompetensi lulusan dan analisis penilaian menggunakan ketentuan pada Tabel 1.

Tabel 1. Kategori Analisis Kebutuhan

\begin{tabular}{rlc}
\hline No & Kategori & Nilai \\
\hline 1 & Sangat baik & $90<\mathrm{N} \leq 100$ \\
2 & Baik & $75<\mathrm{N} \leq 90$ \\
3 & Cukup & $60<\mathrm{N} \leq 75$ \\
\hline
\end{tabular}

(Kemendikbud,2013)

\section{HASIL DAN PEMBAHASAN}

\section{HASIL}

Hasil penelitian merupakan persentase analisis kebutuhan modul siswa berbasis pendekatan STEM pada pembelajaran fisika yang dilakukan pada salh satu kelas XI MIPA SMAN 9 Padang. Analisis kebutuhan modul berbasis pendekatan STEM meliputi: analisis peserta didik, analisis kegiatan pembelajaran, analisis SKL, dan analisis penilaian. Pertama, analisis peserta didik dilakukan untuk mengetahui kemampuan awal dan karakteristik peserta didik secara individu maupun kelompok. Analisis peserta didik diperoleh melalui kuesioner yang telah diberikan kepada 33 siswa sebagai sampel. Kuesioner terdiri dari lima aspek, meliputi : kemampuan awal (pengetahuan, sikap dan keterampilan), minat, motivasi, gaya belajar, dan kemandirian belajar (Uno, 2009). Setiap aspek tersebut memiliki beberapa indikator dan hasil dari analisis peserta didik terlihat pada Gambar 1. 


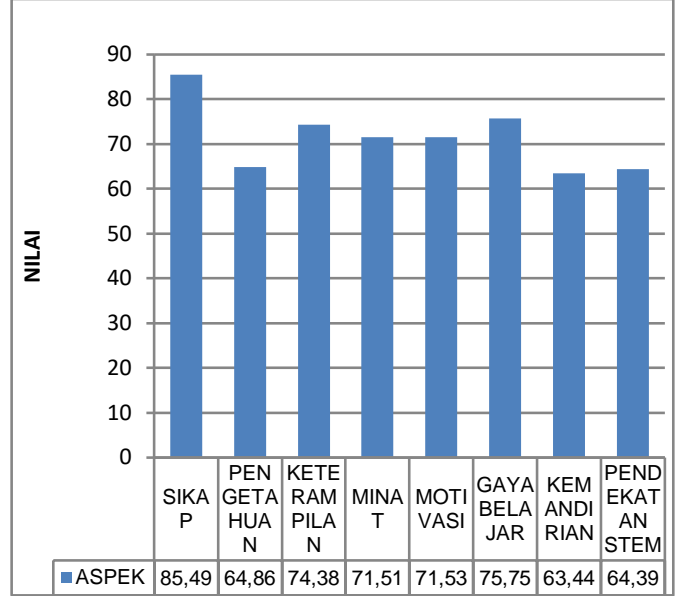

Gambar 1. Analisis peserta didik

Gambar 1 menunjukkan bahwa aspek sikap peserta didik diperoleh nilai 85,49 dengan kategori baik, pengetahuan diperoleh nilai 64,86 berada pada kategori cukup, dan keterampilan memperoleh nilai 74,38 dengan kategori cukup. Aspek minat belajar peserta didik diperoleh 71,51berada pada kategori cukup. Motivasi belajar memperoleh nilai 71,53 dengan kategori cukup. Gaya belajar diperoleh nilai 75,75 dengan kategori cukup. Kemandirian belajar diperoleh nilai 63,44 masuk kategori cukup. Pembelajaran dengan pendekatan STEM 64,39 masuk kateria cukup. Secara keseluruhan analisis peserta didik didapati rata 71,42 masuk kategori cukup. Berdasarkan hasil ini dapat dijelaskan bahwa kemampuan awal dan karakteristik peserta didik dalam pembelajaran fisika perlu ditingkatkan pada aspek pengetahuan, keterampilan, minat, motivasi, gaya belajar dan kemandirian belajar peserta didik.

Hasil kedua dari hasil kuesioner adalah analisis kegiatan pembelajaran yang diisi oleh pendidik. Secara umum, kegiatan pembelajaran terdiri dari atas kegiatan pendahuluan, pelaksanaan, penggunaan model dan metode, media pembelajaran, sumber belajar dan kegiatan penutup. Semua analisi kegiatan pembelajaran diambil dari Permendikbud no.22 tahun 2016. Setiap aspek kegiatan pembelajaran terlihat pada gambar 2 .

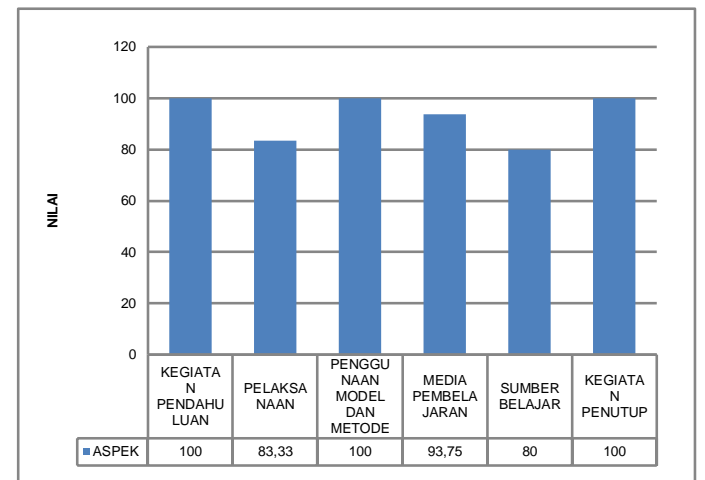

Gambar 2. Analisis kegiatan pembelajaran

Gambar 2 menunjukkan bahwa aspek kegiatan pendahuluan, penggunaan model dan kegiatan penutup diperoleh nilai 100 masuk kategori sangat baik. Aspek pelaksanaan memperoleh nilai 83,33 termasuk aspek baik. Aspek media pembelajaran memperoleh nilai 93,75 masuk kategori sangat baik. Kemudian untuk aspek sumber belajar memperoleh nilai 80 masuk kategori baik. Berdasarkan hasil analisis dapat dijelaskan bahwa semua aspek telah terlaksanakan dengan baik. Sehingga perlu mempertahankan dan meningkatkan pada masa mendatang.

Hasil ketiga adalah analisi penilai dan analisis standar kompetensi lulusan (SKL) memperoleh hasil kuesioner yang telah terisi oleh pendidik. Analisis penilaian dilihat dari aspek yaitu perencanaan penilaian, pelaksanaan penilaian dan pelaporan mendapat nilai 100 masuk pada kategori sangat baik. Nilai sempurna ini menunjukkan bahwa melakukan sistem penilaian dengan sangat baik. sehingga perlu mempertahankan. Selanjutnya analisis SKL, analisis ini dijadikan kriteria mengenai kualifikasi kemampuan lulusan yang mencakup aspek sikap, pengetahuan dan keterampilan. Pada setiap aspek sikap, pengetahuan dan keterampilan terlihat pada gambar 3 .

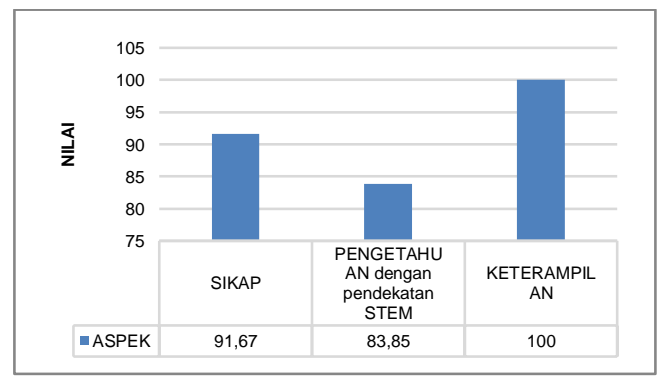

Gambar 3. Analisis SKL 
Gambar 3. Menunjukkan bahwa analisis standar kompetensi lulusan (SKL) untuk aspek sikap diperoleh nilai 91,67 dengan kategori sangat baik, pengetahuan dengan pendekatan STEM diperoleh nilai 83,85 masuk kategori baik dan aspek keterampilan diperoleh nilai 100 denagn kategori sangat baik. Secara keseluruhan analisis SKL mendapatkan nilai yang tinggi masuk kategori sangat baik. Jika dibandingkankan dengan analisis peserta didik didapatkan sedikit kesenjangan dari nilai yang diperoleh. Hal ini menunjukkan harus ada upaya yang dilakukan sehingga peserta didik dapat memperoleh semangat belajar dan motivasi sehingga hasil belajar meningkat.

\section{PEMBAHASAN}

Melalui analisis data aspek sikap berada pada nilai yang paling tinggi hal ini menunjukkan sistem penilaian telah terlaksana dengan baik dalam proses pembelajaran fisika. Sedangkan, kemampuan awal peserta didik masih rendah. Kemampuan awal merupakan kemampuan yang telah diperoleh oleh peserta didik sebelum memperoleh pengetahuan yang lebih besar lagi. Hasil analisis peserta didik untuk pengetahuan, kemandirian dan pembelajaran menggunakan pendekatan STEM masih rendah, perlu ditingkatkan lagi. Minat belajar peserta didik rendah. Peningkatkan minat belajar peserta didik perlu dilakukan upaya salah satunya mengembangkan bahan ajar yang sistematis, menarik bisa digunakan peserta didik belajar secara mandiri, salah satunya modul fisika. Bahan ajar yang akan dikembangkan disesuaikan dengan kebutuhan dan karakteristik peserta didik. Penggunaan bahan ajar menjadi salah satu komponen penting dalam mendukung pembelajaran di sekolah (Andi, 2011). Modul adalah bahan ajar yang dapat digunakan secara mandiri tersusun sistematis oleh peserta didik. Menurut Widiastuti dan Indriana (2019) tantangan abad 21 dengan kompetensi 4C, upaya yang dilakukan untuk pencapaiannya dengan membuat bahan ajar pendekatan STEM, mengkaitkan sains, teknologi, teknik dan matematika dalam penerapan pada kehidupan sehari-hari. Pengintegrasian ilmu pengetahuan alam, teknologi, teknik, dan matematika dalam pembelajaran terbukti meningkatkan kualitas hasil pembelajaran sehingga pendidikan berbasis STEM ini berkembang sangat pesat dalam beberapa tahun terakhir. Menurut Marrison (2006) pendidikan STEM bertujuan untuk membuat siswa menjadi problem solver, penemu, memiliki inovasi, mandiri berpikir logis, melek teknologi, mampu menghubungkan budaya dan sejarahnya dengan pendidikan, serta mampu menerapkan pengetahuannya dalam kehidupan nyata.

Pengembangan bahan ajar berbasis STEM juga dilakukan oleh Desy Rachmawati dkk (2017). Bahan ajar yang dikembangkan adalah modul untuk pembelajaran kimia dasar pada materi laju reaksi. Hasil uji kelayakan bahan ajar menunjukkan nilai sangat valid dan sangat praktis digunakan di dalam pembelajaran. Widya Nessa dkk (2017) juga mengembangkan buku ajar berbasis STEM untuk materi jarak pada ruang tiga dimensi. Buku ajar ini telah divalidasi dan berada pada kategori valid serta telah digunakan di dalam pembelajarn dan terbukti dapat meningkatkan hasil pembelajaran.

Hasil penelitian mengenai analisis kegiatan pembelajaran, semua aspek telah dilakukan dengan sangat baik. Begitu juga pada hasil analisis penilaian dengan semua aspek bernilai sangat baik, hal ini menunjukkan bahwa sistem penilaian telah dilakukan dengan optimal. Terakhir yang dibahas mengenai analisis standar kompetensi lulusan (SKL). Terlihat pada grafik untuk ketiga aspek, sikap , keterampilan, dan pengetahuan dengan pendekatan STEM memperoleh nilai sangat baik. Hal ini menunjukkan bahwa standar kompetensi lulusan disekolah tersebut sudah dilakukan dengan sangat baik. Berarti untuk SKL, penilaian, kegiatan pembelajaran telah dilakukan dengan baik oleh pendidik berarti dipertahankan dan ditingkatkan lagi oleh guru untuk meningkatkan kemampuan peserta didik.

\section{PENUTUP}

Berdasarkan analisis kebutuhan yang telah dilakukan dapat disimpulkan bahwa ratarata analisis peserta didik diperoleh 71,42 berada pada kategori baik, masih banyak beberapa indikator masuk kategori cukup. Perlunya suatu upaya untuk mengatasi berbagai kekurangan yang diperoleh dari 
analisis peserta didik. Salah satunya diperlukan adanya pengembangan bahan ajar dengan pendekatan yang dapat mendukung proses pembelajaran Fisika berupa modul berbasis pendekatan STEM. Pembelajaran STEM yang menggabungkan saint, teknologi, matematika dan teknik sehingga tidak saja berusaha meningkatkan pengetahuan peserta didik tetapi juga berupaya meningkatkan skill atau keterampilan mempersiapkan peserta didik untuk mampu menghadapi dunia kerja.

Analisis kegiatan pembelajaran nilai rata-rata 92,84 berada pada kategori sangat baik. Analisis penilaian dipeoleh rata-rata nilai 100 masuk kategori sangat baik. Analisis standar kompetensi lulusan (SKL) nilai rata-rata yang didapat 91,84 masuk kategori sangat baik. Secara keseluruhan analisis yang didapatkan bahwa pendidik sudah melakukan dengan sangat baik.

\section{UCAPAN TERIMAKASIH}

Terima kasih kepada kepala sekolah SMA N 9 Padang yang telah mengizinkan observasi awal, dan terima kasih kepada peserta didik kelas XI MIA 9 SMA N 9 Padang yang turut berpartisipasi dalam penelitian ini.

\section{REFERENSI}

Arikunto, Suharsimi. (2008). Dasar-Dasar Evaluasi Pendidikan. Jakarta: Bumi Aksara.

Asrizal, A., Rafika, E., \& Triana, A. (2018). Pengembangan LKS IPA Terpadu Tipe Terhubung Berbasis ICT Mengintegrasikan Nilai Karakter Untuk Implementasi Standar Proses Pada Siswa SMP Kelas VIII. DOI 10.17605/OSF.IO/5C6AE

Beers, S. (2011). 21st Century Skills : Preparing Students For Their Future. http://www.yinghuaacademy.org/wpco ntent/uploads/2014/10/21stcenturyskill s.pdf

$\mathrm{JH}, \mathrm{T} . \mathrm{S}$. (2018). Pengembangan e-modul berbasis web untuk meningkatkan pencapaian kompetensi pengetahuan fisika pada materi listrik statis dan dinamis SMA. WaPFi (Wahana Pendidikan Fisika), 3(2), 51-61. https://ejournal.upi.edu/index.php/WP F/article/view/13731

Lestari, I. (2013). Pengembangan Bahan Ajar Berbasis Kompetensi. Padang : Akademia.

Majid, A. (2008). Perencanaan Pembelajaran. Bandung: PT Remaja Rosdakarya

Marrison. (2006). Attribute of STEM Education (online)(http://www.psea.org). Diakses tanggal 01 September 2021

Nessa, W., Hartono, Y., \& Hiltrimartin, C. (2017). Pengembangan buku siswa materi jarak pada ruang dimensi tiga berbasis Science, Technology, Engineering, and Mathematics (STEM) Problem-Based Learning di kelas X. Jurnal Elemen, 3(1), 1-14. DOI: https://doi.org/10.29408/jel.v3i1.2 $\underline{73}$

Permendikbud Nomor 22 Tahun 2016 tentang Standar Proses. Jakarta : Depdikbud.

Permendikbud Nomor 26 Tahun 2016 tentang Standar Sarana dan Prasarana. Jakarta : Kementrian Pendidikan Dan Kebudayaan Republik Indonesia.

Rachmawati, D., Suhery, T., \& Anom, K. (2017, October). Pengembangan modul kimia dasar berbasis STEM problem based learning pada materi laju reaksi untuk mahasiswa program studi pendidikan kimia. In Seminar Nasional Pendidikan IPA (Vol. 1, No. 1, pp. 239-248).

Sugiyono. (2017). Metode Peneitian Kuantitatif, Kualitatif, dan R\&D. Bandung : Alfabeta.

Sukardi. (2007). Evaluation of Education. Jakarta : Earth Literacy.

Torlakson, Tom, et al. (2014). Innovate: $A$ Blueprint for Science, Technology, Engineering, and Mathematics in California Public Education. California : State Superintendent of Public Instruction.

Uno, Hamzah B. (2009). Model Pembelajaran Menciptakan Proses Belajar Mengajar 


\section{\begin{tabular}{l|l|l} 
Analisis Kebutuhan Pengembangan Modul Pembelajaran Fisika ... & 101
\end{tabular} \\ Yonira Mike Vindi Marta, Ramli}

yang Kreatif dan Efektif. Jakarta : PT Bumi Aksara.

Prastowo, Andi. 2011. Panduan Kreatif Membuat Bahan Ajar Inovatif. Yogyakarta : Diva Press

Widiastuti, A., \& Indriana, A. F. (2019). Analisis Penerapan Pendekatan STEM untuk Mengatasi Rendahnya Kemampuan Berpikir Kreatif Siswa pada Materi Peluang. UNION: Jurnal IImiah Pendidikan Matematika, 7(3), 403. http://dx.doi.org/10.30738/union. v7i3.5895 